\title{
The Significance of English Language Development for Future Asian Tourism and Hotel Management Professionals
}

\author{
Jia Hui Zou \\ Universidad Técnica de Machala, Machala, Ecuador \\ Stephanie Isabel Molina Ramirez \\ Universidad Técnica de Machala, Machala, Ecuador \\ Mayra Alexandra Cuenca Erazo \\ Universidad Técnica de Machala, Machala, Ecuador \\ Maria Asuncion Rojas Encalada \\ ELT Innovators Research Group, Universidad Técnica de Machala, Machala, Ecuador
}

\begin{abstract}
The present study is a systematic review that explores existent research on the significance of developing English at schools and universities, and the impact of English for Specific Purposes (ESP) courses to acquire specialized English for businesses, mainly on the Asian Tourism and Hotel Management sector. Because of ESP complexity, it is recommended to be taught to students of intermediate-advanced English level. Consequently, future professionals will be capable of communicating in the target language around the world and be ready to take these specialized English courses. It also considers the advantages of having appropriate English fluency in the Tourism and Hotel Management sector, and the disadvantages of not having English fluency in this field.
\end{abstract}

Index Terms-fluency, Academic English, English for Specific Purposes, Hotel and Tourism Management, Asia, business professionals

\section{INTRODCTION}

The present article is a systematic literature review that explores previous studies regarding the importance of learning English at school and the influence of ESP courses at the university to develop specialized English for businesses, specifically on the Tourism and Hotel Management sector in Asia.

ESP originated from the need to learn English related to specific professional settings. The world is being developed through the years, and the use of the target language is more important in sectors such as Tourism and Hotel Management. Consequently, with the development of a foreign language, the opportunities of a nation improve (González Ramírez, 2015).

Learning a foreign language brings advantages to everyone's lives, teaches new information such as culture, customs and even knowing a new way of life. However, mastering a new language requires time and effort to acquire communicative skills. According to Baturkmen (as cited in Ahmed, 2014), English is a channel for scientific and technological improvements since it is an essential element for the social and economic advancements. In this respect, ESP is an approach used for specific groups, mostly aimed at university students who need English for their career development. In ESP courses instructors apply innovated methods for teaching which resembles real-life situations in a workplace.

It is recommended that ESP courses be taught to students of intermediate-advanced English level due to its complexity (Lawrence, 2015). For this reason, the following lines of this article explain how Asian schools and universities are emphasizing the development of English, so learners will be capable of communicating in the target language around the world, and be ready to take this specialized English courses to prepare them for their future professions. It also points out the advantages of having appropriate English fluency in the Tourism and Hotel Management sector, and the disadvantages of not being English fluent in this field.

\section{PREPARING FutURE ASIAN PROFESSIONALS}

\section{A. Information and Communication Technologies to Develop English in Asia}

Countries such as Vietnam and Malaysia use Information and Communication Technologies (ICTs) to apply a 
technique called Digital Storytelling which is a tool to strengthen the instruction process in English as a Second Language (ESL) classes.

Even though ICTs cannot be considered as a panacea for all educational issues, its advantages are evident. ICTs facilitates instruction and learning processes. Instructors are enabled to use innovation in their classes. It also helps students to be involved with English through movies that show different situations and cultures (Bui, 2015).

Experts at the University of Houston maintain that more important is the opportunity for autonomous learning through discovering, as it occurs in the Constructivism Theory. Digital Storytelling, in this respect, is appropriate for discovering learning because it encourages students to use technologies such as audio, videos, and images to transmit information as a story (Bui, 2015). The Constructivism Theory has had a significant influence in education, and its creator was Lev Semionovich Vygotsky (1896-1934), who supported the idea that knowledge is the result of the sum of previous knowledge (Cetz Canche, Vázquez Garcia, \& Santiago León, 2015).

\section{B. English Teacher Training in Asia}

Nowadays, the world is becoming more and more globalized, and countless people are learning English, which is regarded as the language most frequently used around the globe, and a common language in Asia. Due to the development of the economy and globalization, the emphasis on English is increasing, and many students make considerable effort to studying English. Innumerable countries where English is not used as a mother tongue strive to improve English education through educational reforms. Thus, the roles of English teachers have become increasingly crucial in educational institutions.

In 2008, Jo wrote a book about English education and teacher education in South Korea. If someone wants to be a teacher in this country, applicants need to attend education courses run and managed by teachers in educational institutes and acquire a teaching certificate relevant to a given category. In other words, in South Korea, teachers need specific qualification criteria for each category. For example, an English teacher and a librarian need different licensed. Then, to strengthen teachers' educational capacity in South Korea, there is an evaluation system. This assessment process effectively enhances the professional capabilities of teachers to enrich the expertise of all of them.

\section{The Importance of Having Native Speakers to Develop English at Schools}

Unfortunately, some students can spell English words but are incapable of speaking them fluently. Furthermore, Exam-oriented education makes many schools emphasize passing the English exams, which leads to the lack of speaking environment for students to practice their speaking skills. As a consequence, they cannot use English after finishing schooling for not having opportunities to talk with native speakers (Ahn, 2015).

With the increasing need to improve the English curriculum, the Seoul Metropolitan Office of Education (SMOE) announced that it would gradually invite more native speakers of English to every elementary and middle school as a way of improving communication skills in English. In 2005, SMOE recruited and placed Native Speaker English Teachers at 100 elementary and middle schools in Seoul (Ahn, 2015).

\section{Teaching English in Chinese Universities}

The development of reading, writing, listening and speaking skills seek to improve the target language. Listening and speaking practice enhance the accent and generate more fluency for daily communication. Meanwhile, reading and writing have a vital connection among them since their development broaden the vocabulary, and improves spelling (Manaj Sadiku, 2015).

Without a doubt, academic English dynamize essential skills in learners. However, one of the most severe problems that affect university students is the development of writing skills which according to the findings, it indicates that their deficiency occurs not because of the instruction they receive from teachers, but because of the students' disability. The cause of this problem is due to the students' belief that writing is the least useful skill for the future. For this reason, teachers have students practice writing through essays and formal emails. In this way, learners identify grammatical errors or common issues when writing (Mo, 2012).

Even though English is considered essential for worldwide communication in the Asian continent, learning the target language for Chinese students and teachers is a challenge since there are few opportunities to practice English in real life situations, and there is lack of authentic material in that language. However, the practice of English goes beyond speaking since this language is used in international businesses such as Tourism and Hotel Management. Likewise, students and teachers who need to practice this language seek for ways to develop it outside classrooms. There are places called "English Corners" in different Chinese cities that aim to interact with different people to improve and avoid the carelessness of this language (Gil, 2008).

\section{E. The Importance of ESP in Malaysia}

According to Medrea \& Rusa (2012), ESP is used exclusively for students who require specialized needs following its major of study. It also seeks not only to be a lingua franca that serves to communicate with the outside world but also to establish future labor relations to position someone towards great job opportunities.

ESP is an approach that refers to the English teaching-process, not in a generalized way but in a more specific direction, that is, it can be oriented to the career one is pursuing, to the profession or a job. So how influential will ESP 
be in an Asian country such as Malaysia?

An article intended to learn the use of English by executives from Malaysia in the commercial sector demonstrated that "The most frequent language sub-skills used are: listening to social conversations in business, speaking on the telephone, reading and writing routine letters and memos. In term of the order of importance, speaking was ranked the highest" (Heng \& Seng Pang, 1996, p. 141).

In this sense, ESP is a tool to develop a business course, and it is suggested to focus more on listening, speaking, reading and writing about social and daily issues of businesses with the purpose to cover the lack of information and the challenges that the professional will face in work environments (Heng \& Seng Pang, 1996).

There are two explicit premises in the results of the study. The first one emphasizes that speaking English is more important than writing. The priority of developing English speaking is under Heng \& Seng Pang study closely related to the capacity of dominating English. The importance of knowing English shows that it is right there where ESP must reinforce abilities and skills. Otherwise, the lack of English knowledge will continue being a disadvantage for the professional. The second premise consists of the need for ESP courses that include real requirements of the industry or work field. Consequently, the number of unemployed professionals who do not know English will be reduced. In the year 2006, the Malaysian government revealed that 45,000 university graduates were unemployed because of not managing the foreign language (Kassim \& Ali, 2010).

\section{F. Teaching ESP at Chinese Universities}

Education is always changing, and the Asian continent is always at the forefront of progress. For this reason, one of its priorities is to offer first class education. According to Lawrence (as cited in ICEF, 2013) Asian universities increasingly welcome more international students who are an essential influence on the global educational development. The Asian nations try to be worldwide leaders, and therefore they give vital importance to English instruction during university studies. Asians perceive this language as a competitive advantage internationally. Consequently, the future professionals are encouraged to improve themselves in their field, specifically in the work area.

Over the years there have been two basic English classes taught at universities. One is College English in which there is much practice on listening, speaking, reading, writing and grammar. The second is ESP that teaches more specialized information. Both types of English teaching are essential in the life of a student. However, the significance of ESP relies on the fact that it relates to the labor field and uses teaching resources such as technology, conferences, study groups, and blogs, all of which boost learning (GUO, 2016).

However, one of the principal problems in ESP, according to Saliu (2013) is that it includes advanced technological terminology, many of which are confused. For this reason, some instructors do not teach specialized English, and when designing a plan of study, they are responsible for looking for information and technological resources. This fact could bring consequences because many essential texts are excluded and the information taught is not adequate for a specific group of students. Therefore, the methodology applied in classes could not be appropriate for ESP. The way a specific topic is taught or the terminology used might be a puzzle to someone who has not been specialized in the area. "Not being a specialist in the specific area, the ESP teacher cannot decide by himself/herself how to adapt the text where important information concerning the subject matter will remain" (Saliu, 2013, p. 4).

\section{G. Importance of English for Asian Businesses}

In the economic sector good speaking English skills is crucial to have a professional competitive advantage. Great entrepreneurs in the world seek for English skillful professionals who work in their organizations, and in this respect, Asia is not the exception.

In regards to the significance of English for Asian businesses, it is necessary to consider that this language is used widely in the mass media in countries such as Hong Kong, India, Malaysia, the Philippines, and Singapore, which use the daily press, and literary traditions of fiction, poetry and other creative writings. Additionally, there is English in other media such as radio and television channels. The expansion of this language in Asia has been caused not only because of economic and social factors but also because of demographics, economic change, technology and educational trends (Bholton, 2008).

Mohd (2002) chief in the Research and Technology Division in an organization specialized in research and industrial development, proposes an idea of business system incubation in Malaysia that is becoming in an approach more and more innovated to develop the active base. Creating and developing products that are innovative, processes and technologies is often a long and expensive process. The creation of a technology-based incubation system with strong business networks, scientific and technological collaborations constitutes an essential channel for the distribution and sharing of knowledge in today's knowledgeable economy. Factors such as technology and the economic result a vital combination of entrepreneurial innovation which has led Malaysia to a considerable expansion outside the continent (Mohd, 2002). For this reason, knowing to communicate in English globally is a competitive advantage for Asia.

In this respect, a study conducted by Evans (2010) in Hong Kong, one of the most important cities in China, evaluated the impact of its policy and economy. The result demonstrated that English is the language to communicate professionally. Even though, the gradual decrease in the significance of English since the Joint Declaration in 1984, the outcomes demonstrate that the importance of written and spoken English has increased during this period. The findings also show the increasing need for Hong Kong to have professionals to communicate in English by their experience 
(Evans, 2010).

In search of learning how important it is the use of English in the Asian businesses, Heng \& Seng Pang (1996) applied a survey to 197 organisations under 5 categories: a) manufacturing, b) commerce, c) service and construction, d) finances, together with questions that considered the time dedicated to the use of English listening, speaking, reading, and writing. The research was conducted with entrepreneurs that use English at work and show that "The business executives claim to have confidence in the use of the language. Thus potential employees must also achieve a level of proficiency that would enable them to use the language confidently and efficiently" (p.141). The results demonstrate that in the commercial area it is essential to develop the abilities to listen and speak English since professionals would continuously need to talk to clients for business reasons. The authors emphasize that the reading and writing skills for letters, agreements, commitment, and memos are also part of daily work. However, the ability to speak and maintain a fluent conversation is the most critical skill (Heng \& Seng Pang, 1996).

According to Hsu (2014) mastering English communication skills among professional of the Hospitality and Tourism $(\mathrm{H} \& \mathrm{~T})$ is a challenge; consequently, the educational and business sectors should work together since communicating with foreign guests is an essential skill. It is necessary, for this reason, to design ESP courses based on the work situation which will be beneficial for students of $\mathrm{H} \& \mathrm{~T}$ programmes as well as educationalists and scientists. In this respect studies on China's hotel industry have resulted in the knowledge that the hotel industry has a central impact on the development of China's tourism industry (Gross, Gao \& Huang, 2013).

\section{ESP TEACHING FOR ASIAN STUDENTS MAJORING IN HOTEL AND TOURISM MANAGEMENT}

\section{A. Advantages of Having Appropriate English Communication Fluency in the Tourism and Hotel Management Sector}

Students majoring in the Tourism and Hotel Management seek to improve their communicative skills since customer service is the most critical element of their career. According to Ying Lu \& Adler (as cited in Canny, Ng \& Burke, 2006), students who acquire abilities to communicate in a specific context are the ones able to position themselves in the Tourism and Hotel Management sector. In this respect, an excellent service relates to proper treatment and outstanding communication, which connects to the knowledge of how to hold a conversation with a tourist depending on the personality, tastes, preferences, and religions. A student must be willing to treat different types of cultures and know how to use the appropriate words and actions.

In recent years Mandarin has been earning its importance in the global communication, and it has been considered by many as the new universal language, which must be learned if one wants to have more job opportunities. However, in the tourism sector, English has a secure connection since is the language used the most nowadays to establish job or personal relationships; therefore, it must not be excluded from the curriculum of universities.

The tourism industry is considered one of the most significant sectors worldwide, which is characterized by the movement of people from one place to another for leisure, business, health, and many other purposes. China is one of the most visited places globally due to its culture and natural attractions, which make this country a journey full of new experiences. Today tourism is not only to visit a place but also get to know its history profoundly, get involved with its culture, so the people responsible for providing service to visitors must know and communicate the information correctly. The Hotel and Tourism staff, besides the attitudes and knowledge in their career, must provide the client right assistance through excellent oral communication. The ability to speak English appropriately is considered as a necessary aspect of customer service which is affected if the language is not handled correctly (Hui Lin, Chih Wu, \& Tsuo Huang, 2013).

Due to the massive influx of tourists to Asia, the offer of tourist and hotel services is continually developing and steadily changing to meet the requirements of visitors, and consequently, the use of English is paramount to communicate. For this reason, future professionals in the tourism sector must learn the language at the university to become competitive workers. For this reason, ESP inclined towards tourism is very important to provide the best service in the area. According to (Hui Lin et al., 2013) learning English that is specific to tourism is different from other sectors since its primary purpose is communication.

In this respect, Lin, Chang, \& Lin (2014) maintain that the development of the globalized tourism market has led international tourist hotels to make hotel adjustments in Taiwan, and develop foreign language proficiency which has proved to be central for communicative skills for undergraduate students and industrial practitioners. Consequently, it has caused an emphasis on collaborative work between educational institutions and hospitality industries. For this reason, designing an English curriculum for hospitality field is vital for the Tourism and Hotel industry.

\section{B. Disadvantages of Not Having Appropriate English Communication Fluency in the Tourism and Hotel Management Sector}

The findings of a study conducted by Huong, Wilkins \& Young (2013) regarding young independent travelers from Asia demonstrated that due to the development of Japan since the 1990s, the economy of South Korea had improved significantly, increasing international travel among young people. The outcomes also show that little ability to speak English fluently was quite tricky. For this reason, opportunities to be English proficient and communicate with native speakers were valuable. Accordingly, male participants of this study described the freedom from the social point of view in their desire to socialize with Westerners and learn about their lifestyle and practice English by drinking together, 
which was sensed as a significant aspect of Western youth culture (Huong, Wilkins \& Young, 2013).

A different study conducted by Wattanacharoensil \& Yoopetch (2012) about the Airline Service Quality in Thailand, centers on the problems of misunderstanding and lack of appropriate English communication. Accordingly, the responsibilities of handling agents in airline operations are essential for efficient performance which leads to positive or negative service quality, which also affects the airlines' prestige.

Furthermore, regular and proper quality language training enables employees to have better English proficiency, and it should be carried out throughout the airline, more specifically in customer service operations. Otherwise, situations of airline employees not able to solve upset customers problems lead to the decrease in customer loyalty or the loss of them. So it is necessary that management invest time and resources in training instead of relying uniquely on observing the employees' performance during the hiring process (Wattanacharoensil \& Yoopetch, 2012). For this reason, the authors of the present study maintain that speaking fluency in the target language constitutes a work opportunity that is not limited to a determined area, but it applies to any other industry. For this reason, in the business world, English is always an advantage because it facilitates the expansion and internationalization of the enterprises.

\section{CONCLUSION}

The existent research explores the significance of developing English at schools and universities, and the impact of ESP courses on the Asian Tourism and Hotel Management sector. It is suggested to teach ESP to students of intermediate-advanced English level. In this regard, future professionals can communicate in the target language worldwide and prepared to take ESP courses. It is also significant to contemplate the advantage of appropriate English fluency in the Tourism and Hotel Management sector and the disadvantages of not being fluent in this professional area.

To have prepared Asian professionals, it is essential to apply Information and Communication Technologies (ICTs) to Develop English skills. Accordingly, countries such as Vietnam and Malaysia use ICTs to practice the target language using a technique called Digital Storytelling which boosts the development of this language.

It is also essential to train English teachers in Asia since many non-English spoken countries attempt to develop English education through educational reforms. Consequently, English teachers are more and more crucial in educational institutions. As a result, if someone wants to become a teacher in South Korea, they are required to attend education courses to obtain a teaching certificate.

Moreover, having native speakers at schools enable learners to practice conversations in the target language. For this reason, SMOE declared that it would steadily invite more native speakers of English to every elementary and middle school to improve English communicative skills.

The development of reading, writing, listening and speaking skills seek to improve the target language in Chinese universities. Listening and speaking practice improves the accent and produces more fluency for daily communication. On the other hand, reading and writing are combined to develop ample vocabulary and better spelling.

Concerning the Importance of ESP in Malaysia, it was found that speaking was considered as having the enormous significance. The increased evolution of this language in Asia has been caused because of demographics, economic change, technology and educational trends which have led Asians to seek for means to develop English conversational skills to have a competitive advantage in the labor market.

Finally, ESP teaching for Asian students who major in Tourism and Hotel Management presents some advantages and disadvantages of having or not appropriate English communication fluency. These students strive to develop their communicative skills since customer service has the most significant impact on their future professions. On the contrary, not having appropriate English communication fluency in the Tourism and Hotel Management sector present some disadvantages to function efficiently in this area, such as independent traveler not able to hold a conversation with native speakers and not giving a good Airline Service Quality to customers. The authors of the present study recommend further research on the different teaching techniques that educators use in Asia to develop ESP that centers in Tourism and Hotel services.

\section{ACKNOWLEDGMENTS}

The authors wish to thank the authorities of Universidad Técnica de Machala for the unconditional support to carry out the present research.

\section{REFERENCES}

[1] Ahmed, M. K. (2014). The ESP Teacher: Issues, Tasks, and Challenges. Chittagong: English for Specific Purposes World, 15.42, 1-33.

[2] Ahn, H. (2015). Awareness of and attitudes to Asian Englishes: a study of English teachers in South Korea. Asian Englishes, 17.2, 132-151. doi: 10.1080/13488678.2015.1036602.

[3] Bolton, K. (2008). English in Asia, Asian Englishes, and the issue of proficiency. English Today, 24(02), 3-12. doi: $10.1017 / \mathrm{S} 026607840800014 \mathrm{X}$.

[4] Bui, K. N. (2015). Teachers" Concerns and Solutions Towards The Implementation of Digital Storytelling in Teaching English in ESL Classroom in Asian Countries. Journalism and Mass Communication, 5.9, 454-462. doi: 10.17265/2160$6579 / 2015.09 .002$ 
[5] Cetz Canche, N. J., Vázquez García, M. D., Santiago León, W. M. (2015). Educación con tecnología multimedia: una experiencia en sistemas digitales. Dialnet, 57, 17-25.

[6] Evans, S. (2010). Business as usual: The use of English in the professional world. English for Specific Purposes, 29.3, 153-167. doi:10.1016/j.esp.2009.11.005.

[7] Gil, J. (2008). China's English Language Environment. English Language Teaching, 1.1, 1-9.

[8] González Ramírez, C. (2015). English for Specific Purposes: Brief History and Definitions. Costa Rica: Revista de Lenguas Modernas, 23, 379-386.

[9] Gross, M.J, Gao, H. \& Huang, S. (2013). China hotel research: A systematic review of the English language academic literature Tourism Management Perspectives, 6, 68-78.

[10] GUO, S. R. (2016). Research on Integration of College English Teaching and ESP Teaching. Shenyang, Liaoning, China: 2016 3rd International Conference on Advanced Education and Management.

[11] Heng, C. S. \& Seng Pang, S. G. (1996). The Use of English by Malaysian Business Executives in the Commercial Sector. Pertanika J. Soc. Sci. \& Hum, 4.2, 154-164.

[12] Hui Lin, C., Chih Wu, W., \& Tsuo Huang, Y. (2013).English for Specific Purposes (ESP) for Hospitality College Students and Hotel Employees in Taiwan. International Journal of Education and Research, 1.8, 1-14.

[13] Jo, S. (2008). English education and teacher education in South Korea. Journal of Education for Teaching: International research and pedagogy, 34.4, 371-381. doi:10.1080/02607470802401594.

[14] Kassim, H. (2010). English communicative events and skills needed at the workplace: Feedback from the industry. English for Specific Purposes, 29.3, 168-182. doi:org/10.1016/j.esp.2009.10.002.

[15] Lawrence, A. (2015). The Changing Role and Importance of ESP in Asia. Tainan, Taiwan: English as a Global Language Education (EaGLE) Journal, 1.11, 1-21. doi:10.6294/EaGLE.2015.0101.01.

[16] Lin, C., Chang, W. \& Lin, T. (2014). The Study on Constructing a Curriculum Model of Hotel English for Undergraduate Hospitality Management in Taiwan. Theory and Practice in Language Studies, 4.10, 2001-2007. doi::10.4304/tpls.4.10.20012007.

[17] Manaj Sadiku, L. (2015). The Importance of Four Skills Reading, Speaking, Writing, Listening in a Lesson Hour. Elbasan Albania: European Journal of Language and Literature Studies, 1.1, 29-31.

[18] Medrea, N., \& Rusa, D. (2012). Challenges in ESP: teaching resources and students needs. Procedia Economics and Finance. 3 1165-1169. doi:10.1016/S2212-5671(12)00291-2.

[19] Mo, H. (2012). A Study of the Teaching of ESL Writing in Colleges in China. Guangxi, China. International Journal of English Linguistics, 2.11. doi:10.5539/ijel.v2n1p118.

[20] Mohd, G.M., (2002): Building an innovation-based economy: The Malaysian technology business incubator experience. Journal of Change Management. 3(2), 177-188. doi:10.1080/714042527.

[21] Saliu, B. (2013). Challenges for learners/ teachers in the esp course for legal studies. Versita, 9.1, 1-8. doi: 10.2478/seeur-20130001.

[22] Ying Lu, T., \& Adler, H. (2009). Career Goals and Expectations of Hospitality and Tourism Students in China. Indiana: Journal of Teaching in Travel \& Tourism, 9.1, 63-80. doi: 10.1080/15313220903041972.

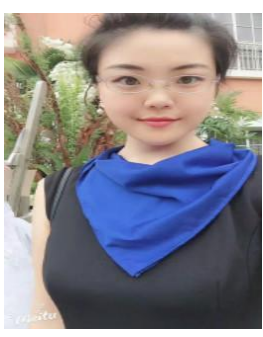

Jia H. Zou was born in Beijing the capital of China in the year 1993. She is getting her Bachelor's Degree in Tourism and Hotel Management at Universidad Técnica de Machala (UTMACH).

She has been working as a Chinese Language Tutor and also doing practical training with a travel agency and a five-star hotel. She collaborated in activities to improve the tourism in a small community in the province of El Oro. Currently, she is a member of a research group at UTMACH called ESP Researchers where she is conducting various studies related to her field.

Because English is an essential language for the Tourism industry, Ms. Zou completed and approved an online English Conversation Course organized by the United States Mission. She has also accomplished level 8 of English in a language institute at UTMACH.

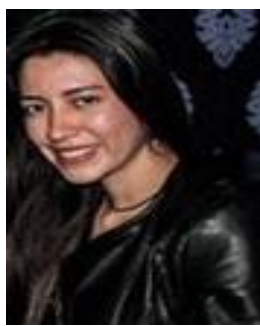

Stephanie I. Molina was born in the city of Piñas located in the Province of El Oro in Ecuador in the year 1996. She is getting her Bachelor's Degree in Tourism and Hotel Management at Universidad Técnica de Machala (UTMACH)

During her university studies, she has been working in the hotel industry to get the full experience of her academic major. She has also worked in activities related to tourism in the community around the province of El Oro to collect information of the touristic attractions. Currently, she is a member of a research group at UTMACH called ESP Researchers to conduct various studies related to her field.

Ms. Molina was awarded the Certificate of Achievement B2 Upper Intermediate provided by Education First in the year 2016 in Toronto, Canada. 


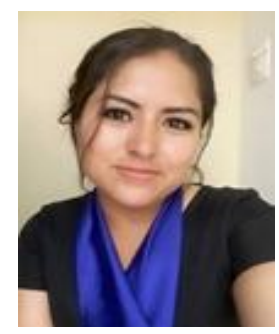

Mayra A. Cuenca was born in 1993 in the city of Piñas located in the Province of El Oro in Ecuador. She is about to get her Bachelor's Degree in Tourism and Hotel Management at Universidad Técnica de Machala (UTMACH).

During her university studies, she has done practical training in the tourism sector such as Travel Agencies and Tourism Operators in the city of Machala. She has also worked in activities related to tourism in the community around the province of El Oro to collect information of the touristic attractions. Nowadays she is a member of a research group at UTMACH called ESP Researchers.

Ms. Cuenca has completed and approved the fifth level of English in a Language Institute at UTMACH.

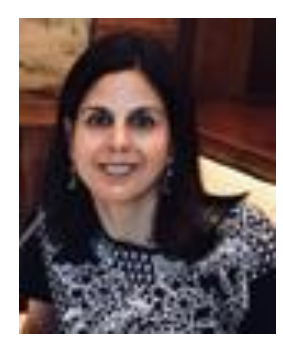

Maria A. Rojas is an Ecuadorian professor and researcher. In the year 2017, she earned a Master's Degree in Teaching English as a Foreign Language at Escuela Superior Politécnica del Litoral (ESPOL) in Ecuador. She is currently studying her PhD in Advanced English Studies at the University Of La Coruña, Spain. Her primary field of study focuses on English Language Teaching (ELT). She has been working as an ESP professor at Universidad Tecnica de Machala (UTMACH) in Machala, Ecuador since the year 2014.

Prof. Rojas is a member of a Research Group called ELT Innovator at UTMACH. Some of her recent publications are The Influence of Implementing Role-play as an Educational Technique on EFL Speaking Development (Theory and Practice in Language Studies, 2018). Collaborative Work and Technological Means for improving Learners' English Language Writing Production (Turkish Online Journal of Educational Technology, 2017), Performance-Based Tasks as a Mean to Assess the Speaking of Learners of English as a Foreign Language (Turkish Online Journal of Educational Technology, 2017), and English Language Teaching Approaches: A comparison of the Grammar-Translation, Audio-lingual, Communicative, and Natural Approaches (Theory and Practice in Language Studies, 2017). 